\title{
Harvest Retention Survivorship of Endangered Whitebark Pine Trees
}

\author{
Michael P. Murray ${ }^{1, *}$, Jenny Berg ${ }^{2}$ and David J. Huggard ${ }^{3}$ \\ 1 British Columbia Ministry of Lands and Natural Resource Operations, \#401-333 Victoria Street, \\ Nelson, BC V1L 4Y9, Canada \\ 2 Department of Geography, University of Victoria, Victoria, BC 58P 5C2, Canada; vedaworks@gmail.com \\ 3 Apophenia Consulting, 517 E.10th St., North Vancouver, BC V7L 2E7, Canada; dhuggard@telus.net \\ * Correspondence: michael.murray@gov.bc.ca
}

Citation: Murray, M.P.; Berg, J.; Huggard, D.J. Harvest Retention Survivorship of Endangered Whitebark Pine Trees. Forests 2021, 12, 654. https://doi.org/10.3390/ f12060654

Academic Editor: Daniel J. Johnson

Received: 6 May 2021

Accepted: 19 May 2021

Published: 21 May 2021

Publisher's Note: MDPI stays neutral with regard to jurisdictional claims in published maps and institutional affiliations.

Copyright: (c) 2021 by the authors. Licensee MDPI, Basel, Switzerland. This article is an open access article distributed under the terms and conditions of the Creative Commons Attribution (CC BY) license (https:// creativecommons.org/licenses/by/ $4.0 /)$.

\begin{abstract}
Whitebark pine (Pinus albicaulis Engelm.) is a widely distributed high-elevation species in western North America that is threatened primarily by an introduced disease and other disturbances. In British Columbia, this tree is a component of harvested forests, yet knowledge of post-harvest survivorship and factors that promote successful retention is lacking. Our objectives are to describe the temporal attrition of retained mature whitebark pine trees and to identify factors that likely influence survivorship during the critical initial post-harvest period. We assessed five separate harvest units in southeastern British Columbia. Dendrochronological investigation revealed that retained trees experienced high annual mortality rates (3-16\%) across harvest sites during the initial five-year post-harvest period. By eight years post-harvest, retention survivorship ranged from 17-80\%. After eight years post-harvest, mortality rates drastically declined. The preponderance of fallen stems oriented towards the northeast suggests that storm system events arriving from the Pacific Ocean are the most significant drivers of blowdown. We estimate that survivorship is positively associated with shorter tree heights and longer crown lengths, a lack of disease cankers, a greater presence of rodent wounding, and higher numbers of surrounding retained trees. We found little effect based on slope and aspect. As these trees are an endangered species, harvest operations should be practiced cautiously in associated forests. We recommend carefully selecting retention trees, ensuring an adequate number of neighbor trees, and orienting retention patches to avoid predominant storm wind directions.
\end{abstract}

Keywords: whitebark pine; Pinus albicaulis; harvest retention; post-harvest mortality; forest conservation; windthrow

\section{Introduction}

Whitebark pine (Pinus albicaulis Engelm.), which is widely distributed at higher elevations in western North America, affords notable ecological and cultural services. This tree is a renowned habitat asset for a variety of wildlife, including grizzly bears (Ursus arctos horribilis Ord), foxes (Vulpes vulpes Linnaeus), and Clark's nutcrackers (Nucifraga columbiana Wilson), which consume the large nutrient-rich seeds [1-3]. Historically, whitebark pine has helped sustain the food demands of high-elevation human communities [4]. At the highest elevations of the tree's existence, whitebark pine stabilises shallow steep soils and provides stunted wind-battered forms that are popular among photographers and which provide attractive weather-sheltering campsites.

In 2012, whitebark pine was listed as an endangered species, thus becoming the only designated tree in western Canada [5]. It is also classified as endangered by the International Union for Conservation of Nature [6]. The primary driver responsible for declining populations of whitebark pine is the disease white pine blister rust, caused by the introduced fungus Cronartium ribicola Fischer. During the last two decades, whitebark pine has also been under increasing pressure from the mountain pine beetle (Dendroctonus 
ponderosae Hopkins) and shifting fire regimes. In southeastern British Columbia (BC) and neighboring Alberta, Smith and others [7] estimated that blister rust infections were rising in the region, with tree mortality levels increasing from $26 \%$ to $65 \%$ between 1996 and 2009 . Although blister rust is evident throughout most of its range, this region, including the adjoining Northern Rocky Mountains of USA, is the most heavily impacted [7-9].

In southern BC, whitebark pine trees are common in subalpine mixed-conifer forestsa major portion of the publicly owned timber harvest land base. The most abundant associated tree species are Engelmann spruce (Picea engelmannii Parry ex Engelm.) and subalpine fir (Abies lasiocarpa (Hook.) Nutt.). Whitebark pines increase in abundance with elevations from 1600 to $2100 \mathrm{~m}$. Above $2100 \mathrm{~m}$, stand volumes decrease drastically due to lower growth rates and stem densities. A gradual increase in harvest acreage above 1800 m elevation began in 2008 in the Kootenay Boundary Region. Scrutiny regarding high-elevation harvesting, especially within forests containing endangered tree species, emphasises the socio-ecological risk of such pursuits $[10,11]$. As a mitigation measure, the long-term retention of mature trees can ensure that ecological values are better protected, such as biodiversity, soil health, and hydrologic function.

The persistence of healthy cone-producing whitebark pine is not only beneficial for ecological services, but critical for sustaining this endangered species. Disease-free mature individuals may display host resistance to white pine blister rust [12,13] and represent seed sources for potentially disease-resistant genotypes—serving as progenitors for successful natural regeneration and self-sustainment [14].

Knowledge regarding the fate of mature coniferous trees retained during harvest operations is relatively recent. Preliminary findings from multiple studies suggest that the number of residual white spruce (P. glauca (Moench) Voss) and black spruce (P. mariana (Mill.) Britton, Sterns and Poggenb.) dying is often significant, especially during the initial post-harvest period [15]. A major determining factor for survivorship appears to be the retention level, also referred to as the density and/or basal area of post-harvest residual stems. Higher levels create more wind buffering among trees. Other variables that can affect survivorship include tree species, distance to forest edge, and tree morphology (stem diameter and live crown ratio) [16-19]. Pre-harvest stand conditions can influence tree morphology, as narrowly spaced conditions promote a slender, top-heavy structure, which are characteristics of trees that are vulnerable to windthrow [20]. We are not aware of any harvests in open-canopied whitebark pine stands. Such forest stands tend to be at the upper-most elevations of merchantable tree growth and tend to be much less economical for harvesting.

For whitebark pines retained within commercial harvests, survivorship has not been examined in any study we are aware of. In the Kootenay Boundary region of southeast British Columbia, there are multiple harvest openings where mature whitebark pine trees have been retained. By applying dendrochronological and field inventory procedures, we investigated the fate of residual trees to infer some preliminary recommendations. Our objectives were to describe the temporal attrition of retained mature whitebark pine trees and to identify factors that likely promote survivorship during the critical initial post-harvest period.

\section{Materials and Methods}

\subsection{Study Sites}

Five harvest sites were sampled in southeastern British Columbia during the summer of 2018 (Figure 1). The criteria used for site selection were a minimum post-harvest age of 7 years, a minimum sample size of 20 trees, and accessibility (within a one-hour hike). Practicing foresters (government and private industry) provided the locations of candidate sites. Besides our study sample, all other sites were either too recently harvested, lacked enough whitebark pine, or were inaccessible. Silviculture prescriptions classify these sites as clear-cuts with reserves, thus they are considered variable retention sites and represent the only prescriptive method deployed to date in the region's whitebark pine stands. 
Because harvest years differed among the sites, our field sampling captured a range of post-harvest intervals representing 6-17 years (Table 1). Based on the majority of whitebark pine stands in the region, our study sites are representative of the most common mix of tree species, elevation range, tree ages, and habitat.

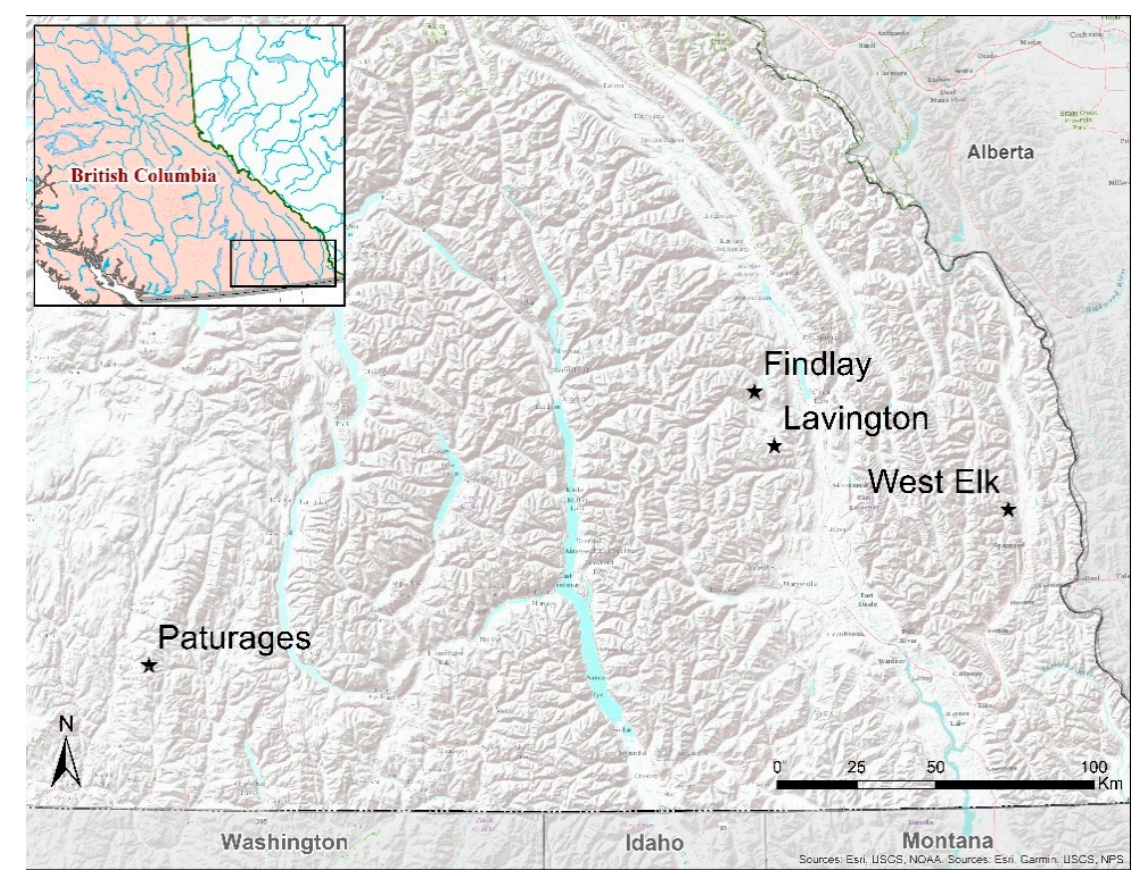

Figure 1. Harvest sites in southeastern British Columbia. Findlay consists of two separate but adjoining harvests units.

Table 1. Summary of five sampled harvest sites in southeastern British Columbia.

\begin{tabular}{cccccc}
\hline Site & Elev (m) & Lat & Long & $\begin{array}{c}\text { Harvest Unit } \\
\text { Size (ha) }\end{array}$ & Harvest Year \\
\hline $\begin{array}{c}\text { Findlay East (FE) } \\
\text { Findlay West }\end{array}$ & 1922 & 50.19303 & -116.0542 & 19.9 & 2006 \\
$\quad$ (FW) & 1960 & 50.19359 & -116.0668 & 4.9 & 2001 \\
Lavington (LV) & 1884 & 50.04018 & -115.9787 & 35.1 & 2012 \\
Paturages Creek & 2001 & 49.40264 & -118.7187 & 30.3 & 2003 \\
$\quad$ (PC) & 1874 & 49.84562 & -114.9571 & 19.5 & $2007-2008$ \\
West Elk (WE) & & & & & \\
\hline
\end{tabular}

Our study sites are classified as Engelmann spruce-subalpine fir (ESSF) biogeoclimatic zones [21]. Paturages Creek is the only site to have the dry cold ESSF (dc) subzone classification [22], whereas the remaining three sites are dry cool ESSF (dk) [23]. The ESSF has a continental climate with relatively cold, moist, and snowy winters. This zone is the uppermost forested zone in the central and southern interior of BC and has high value ascribed to its abundant wildlife, timber, and recreational opportunities [24]. The predominant tree species associated with these sites are Engelmann spruce, subalpine fir, lodgepole pine (Pinus contorta var. latifolia Engelm.), subalpine larch (Larix lyalli Parl.), and whitebark pine. Lavington is rapidly drained, Paturages Creek is well-drained, and the remaining sites are classified as imperfectly drained.

\subsection{Field Sampling}

A census of mature whitebark pine greater than $17 \mathrm{~cm}$ dbh (diameter at breast height) was conducted at each harvest site (Table 2). Trees with smaller diameters were rare, 
subdominants, and poor cone producers. The census approach was selected after site assessments conducted in 2017 revealed considerable spatial variation of reserve trees. For the Paturages Creek harvest unit, we restricted our survey to the upper half of the harvest opening due to time constraints. Trees near the perimeter of the harvest units were excluded if the tree height was greater than the distance to the nearest forest edge. The location of every tree was recorded with a high-precision (GNSS) global positioning device. Each tree stem was spray painted with a blue encircling band and a metal tag with a unique identifier code was nailed to each tree.

Table 2. Mean metrics of whitebark pine trees retained in harvest units, representing all trees (living and dead) surveyed.

\begin{tabular}{ccccc}
\hline Site & No. Trees & Height (m) & Dbh (cm) & Chronology Length \\
\hline Findlay East (FE) & 20 & $21.1 \pm 1.1$ & $45.0 \pm 5.1$ & $243 \pm 65$ \\
Findlay West (FW) & 34 & $15.5 \pm 1.0$ & $28.7 \pm 3.2$ & $177 \pm 58$ \\
Lavington (LV) & 128 & $19.2 \pm 0.4$ & $34.3 \pm 1.2$ & $211 \pm 31$ \\
Paturages Creek (PC) & 103 & $17.4 \pm 0.4$ & $40.4 \pm 1.5$ & $210 \pm 60$ \\
West Elk (WE) & 170 & $17.6 \pm 0.4$ & $33.8 \pm 1.1$ & $184 \pm 56$ \\
\hline
\end{tabular}

Every tree was assessed based on the following parameters: height, diameter (dbh), distance and azimuth to nearest forest edge, height to live crown, and percentage of live crown. We recorded tree bole condition classes (damaged, poor, fair, good). We noted whether each tree was alive or dead. For dead trees, we classified them as standing, broken, or windthrow (fallen). The direction of fall (deg) was noted for every downed tree. The slope (\%) and aspect (deg) were measured at each tree. For every surveyed tree we tallied the number of mature neighbour trees within a distance equal to or less than the survey tree's height. Each neighbour tree was noted according to status (live, snag, down). All trees were examined for forest health agents. Blister rust was evident by the presence of cankers, and these were noted as occurring on stems or branches and being active or inactive [25] with the use of binoculars. Rodent gnawing damage is often an indication of blister rust infection [26], and thus was noted. Mountain pine beetle evidence includes pitch tubes, distinctive wood galleries, and staining.

\subsection{Dendrochronology}

Increment cores were collected from all live and dead reserve trees using a 4-mm Haglof increment borer taken at approximately $1.3 \mathrm{~m}$ above the ground. Standing trees were cored at a $90^{\circ}$ angle perpendicular to the slope to avoid compression wood. Likewise, horizontal trees were cored at a perpendicular angle to the fall line from the past standing condition. To minimise the effects of potential coring on the remaining live WBP reserve trees, we only sampled one core per tree. Standing dead and horizontal dead trees included a minimum of two cores per tree; however, some trees required a third core if the previous two cores showed rot or were severely damaged near the bark end. All cores were air-dried and mounted on slotted boards. Cores were sanded with sequentially higher grit to obtain an annual ring resolution [27]. Those samples with exceptionally condensed rings were measured with a Velmex uniSlide digitally encoded traversing table at a precision of $0.01 \mathrm{~mm}$. The remaining cores were digitally scanned at a $2400 \mathrm{dpi}$ resolution with an HP flatbed scanner. Digital images were imported into CooRecorder measuring software and exported as ring width files with CDendro software package [28]. To ensure that the appropriate calendar date was assigned to each measured ring we used the program COFECHA to aid in accurately cross-dating all increment cores [29]. Dead trees were examined with a microscope to determine if any additional growth followed the last complete growth ring. We added a year to the final death date if earlywood cell development was observed beyond the last complete growth ring. 


\subsection{Characteristics of Retained Trees}

To identify potential factors affecting survivorship, we evaluated a set of models using Akaike's "An Information Criterion" (AIC) [30]. Four sets of biophysical measurements were examined as potential factors to predict the survival of retained whitebark pine trees (Table 3). To reduce the number of variables included in the analysis, correlated variables within each set were screened using AIC model selection. The best subset of variables in each set (underlined in Table 3) was used in the final analysis.

Table 3. Four groups of biophysical variables examined and used in models (underlined) to predict the survival of retained whitebark pine trees.

\begin{tabular}{|c|c|}
\hline Group & Variable \\
\hline Slope and Aspect & $\begin{array}{l}\text { Nfacing- } \cos (\text { aspect }) \times \text { slope-the north-facing component of slope } \\
\text { Efacing- } \cos \left(90^{\circ} \text {-aspect }\right) \times \text { slope-the north-facing component of slope }\end{array}$ \\
\hline Forest Distance & $\begin{array}{l}\text { ForDist—distance to nearest forest edge, truncated at } 200 \mathrm{~m} \\
\text { Sqrt(ForDist) } \\
\text { WindFetch-distance to nearest forest edge in direction } 180^{\circ} \text { from the } \\
\text { mean windfall direction in each site }\end{array}$ \\
\hline Tree Characteristics & $\begin{array}{l}\text { Ht-Height }(\mathrm{m}) \\
\text { CrownLength-Crown length }(\mathrm{m}) \\
\text { CrownRatio-Crown length/height } \\
\text { DBH-Diameter at breast-height }(\mathrm{cm}) \\
\text { HtToDBH-Height:DBH ratio } \\
\text { nCankers-Number of blister rust cankers, active and inactive } \\
\text { combined } \\
\text { Rodent-Presence/absence of rodent damage }(0 / 1)\end{array}$ \\
\hline Surrounding Trees & $\begin{array}{l}\text { SurroundingLiveDown-Number of surrounding live or down trees } \\
\text { SurroundingTotal-Number of surrounding live, standing dead or } \\
\text { down trees }\end{array}$ \\
\hline
\end{tabular}

The final analysis used AIC model selection with 16 models, representing all combinations of including or excluding the selected variables in each of the four sets. All models were general linear mixed-effects models using a binomial distribution (logit link) for the $0 / 1$ response variable (live versus dead). All models include a random effect of site, called an "intercept" [31] because it is an additive constant for each site on the logit scale. The model that excluded all four sets of explanatory variables was the null model, with only the random effect of site. The model that included all four sets was the global model, containing all the selected variables (underlined in Table 3). The other 14 models included the different possible combinations of 1-3 sets of explanatory variables.

The analyses were conducted separately for windthrown versus live trees, and for all dead trees (windthrown and standing dead) versus live trees. Models were fit using the lme4 package in R [32] (details in Supplementary Material).

Mountain pine beetles are known mortality agents for whitebark pine. Thus, dead trees observed in the field with signs of mountain pine attack were removed $(n=30)$. Because our West Elk (WE) study site experienced an outbreak during 2007-2008, we removed only the trees that died during this time with blue-stain fungus at the phloem position of the increment cores $(n=17)$.

\section{Results}

A total of 197 dead trees and 134 live trees were analyzed. Based on dendrochronological examination, mortality rates were highest immediately following harvests (Figure 2). Lavington (LV) experienced a drastic loss of trees during the summer of the harvest. In a single day (20 July 2012), harvest operators reported that most retained trees were blown over during a powerful storm. A negative exponential trend characterized three harvest sites, where initial steep declines became increasingly moderated over time. Findlay West 
(FW) experienced a very high rate of retention. By 6-8 years post-harvest, differences in the proportions of surviving trees between sites became more pronounced, varying from $17 \%$ at Lavington (LV) to $80 \%$ at Findlay West (FW). For the three intermediate sites, mortality ceased at 8-9 years, extending for the remainder of the study period. Of the dead trees surveyed in 2018 , the overall number of fallen trees (84\%) greatly exceeded the frequency of snags $(16 \%)$ and was similar for all sites except Findlay West (FW), where amounts were equal. Across all sites, we found that 32 trees died pre-harvest and sample cores from an additional 45 trees were too rotten to assess; thus, these 77 trees were not included in the analysis.

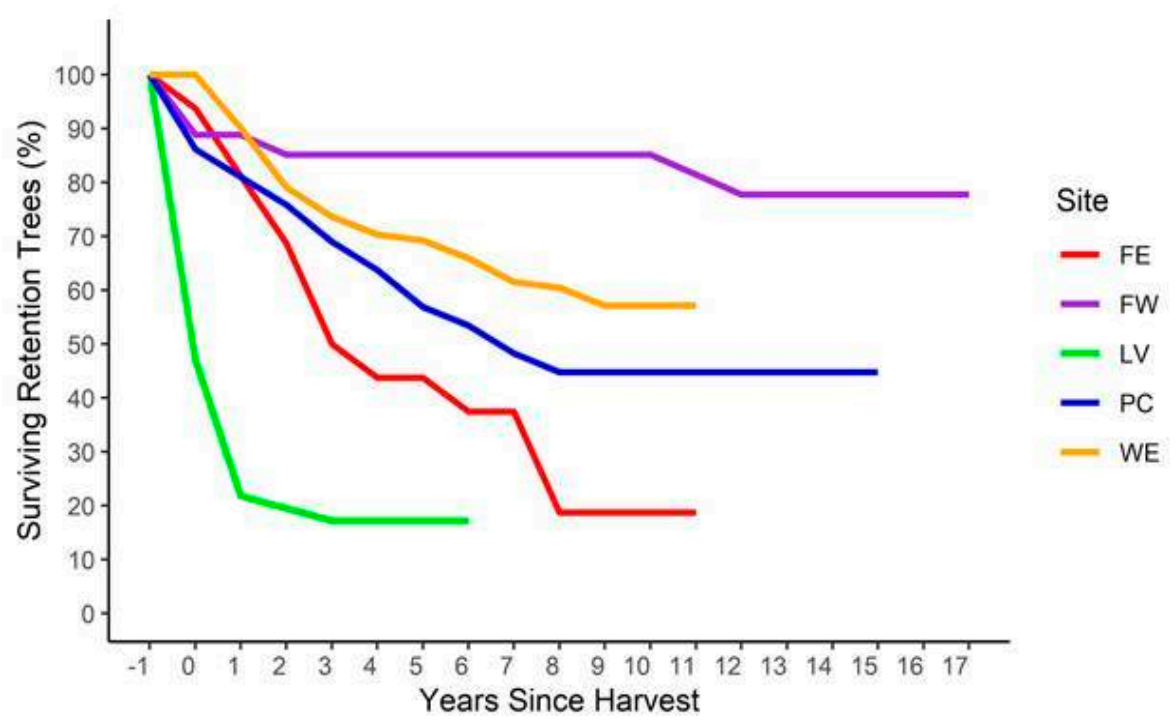

Figure 2. Post-harvest attrition of retained whitebark pine according to harvest site (FE: Findlay East; FW: Findlay West; LV: Lavington; PC: Paturages; WE: West Elk).

We found the vast majority of downed trees to be oriented in a northeasterly direction from root collar to crown (Figure 3). The mean direction of tree fall closely matched the mean slope azimuth at a single site (Paturages). Overall, the predominant northeasterly windthrow azimuths indicated that the strongest winds experienced at the sites arrived from southwesterly directions.

The probability of mortality of retained whitebark pine trees is best explained by a combination of tree characteristics, slope/aspect, and the number of surrounding retained trees (Table 4). We found a strong increase in survivorship, with greater tree crown length accompanied by decreasing tree height. Thus, the probability of post-harvest mortality was higher for taller trees with shorter crowns and lower for shorter trees with long crowns (Figure 4). 

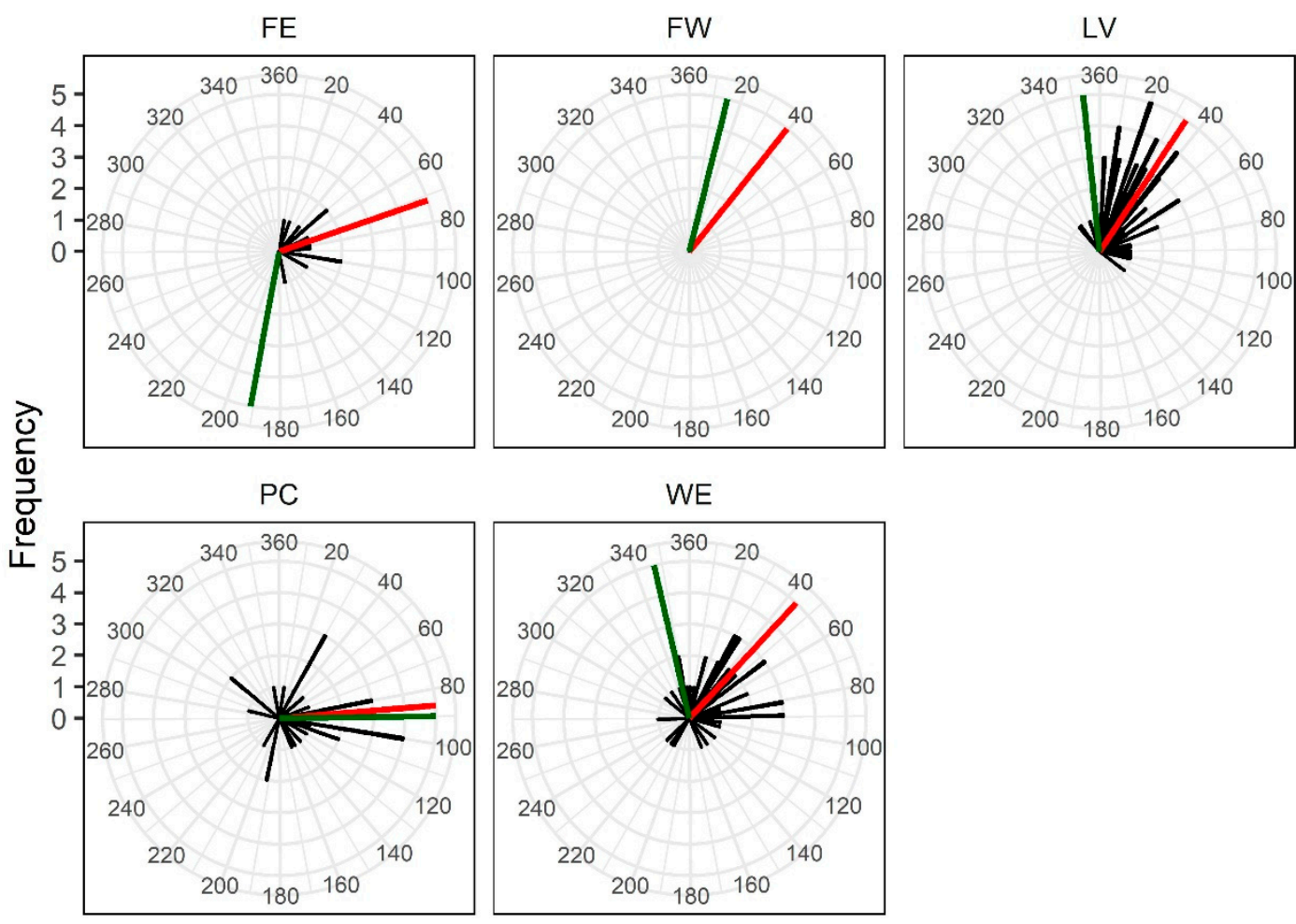

\section{Direction of Windthrow}

Figure 3. Circular histograms of windthrown trees at five harvest sites. Black bars: frequency of trees oriented at the respective azimuth. Red bars: mean azimuth of windthrow orientation. Green bars: mean azimuth of slope aspects as measured at the base of each stem. All FW tree bars match mean windthrow azimuth. (FE: Findlay East; FW: Findlay West; LV: Lavington; PC: Paturages; WE: West Elk).

Table 4. Logit-scale coefficients for the best model for all dead trees (windthrow and snags) and windthrow only.

\begin{tabular}{ccccccc}
\hline & \multicolumn{3}{c}{ All Dead Trees } & \multicolumn{3}{c}{ Windthrow } \\
\cline { 2 - 7 } & Estimate & SE & $p$ & Estimate & SE & $p$ \\
\hline Intercept & -0.918 & 1.154 & 0.427 & -0.792 & 1.353 & 0.558 \\
Nfacing & - & - & - & 2.399 & 1.173 & 0.041 \\
Efacing & - & - & - & -1.907 & 1.268 & 0.132 \\
Sqrt(Surrounding Live Down) & -0.447 & 0.179 & 0.012 & -0.524 & 0.188 & 0.005 \\
nCankers & 0.141 & 0.088 & 0.109 & 0.249 & 0.096 & 0.010 \\
Rodent & -1.760 & 0.397 & $<0.001$ & -2.312 & 0.468 & $<0.001$ \\
Ht & 0.281 & 0.071 & $<0.001$ & 0.2460 & 0.079 & 0.002 \\
CrownLength & -0.342 & 0.069 & $<0.001$ & -0.3351 & 0.074 & $<0.001$ \\
\hline
\end{tabular}

The presence of more surrounding retained trees (within a single tree-height radius) also increased the probability of survival (Table 4). Using the average of the other tree and site variables, a survivorship probability greater than $50 \%$ required a minimum of 7.5 retained neighbor trees (Figure 5). Distance to forest edge was not included in the best model of survivorship. 


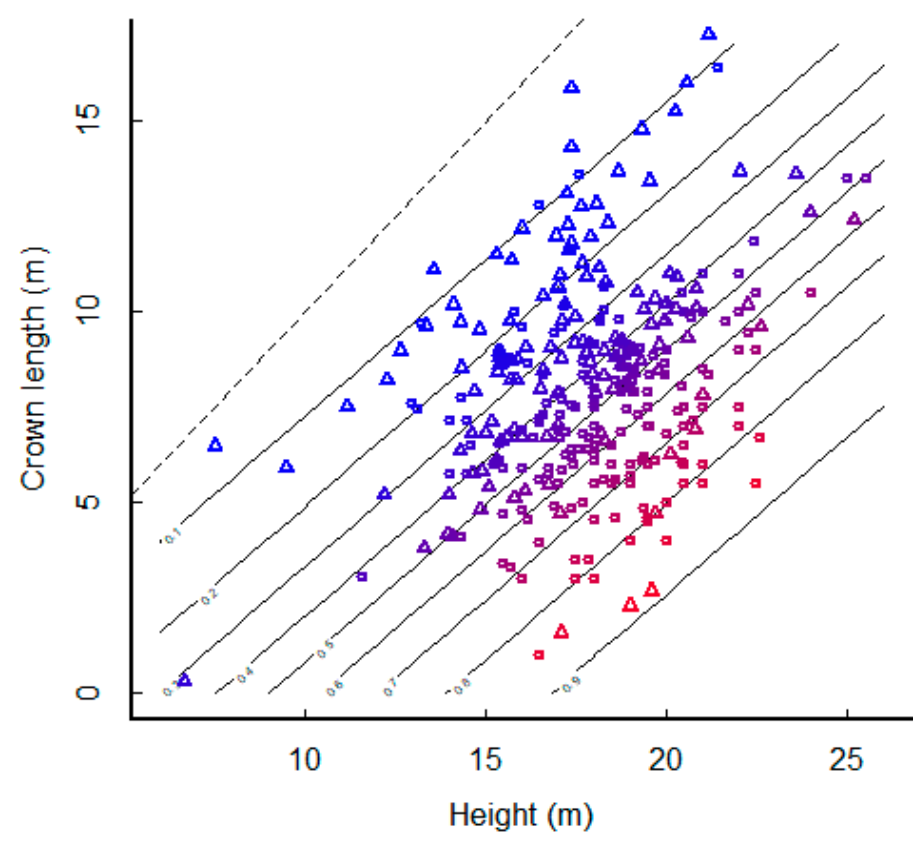

Figure 4. Probability of mortality (symbol colour, from blue $=$ low to red $=$ high) as a function of tree height and crown length. Labelled contour lines also show the probability at each combination of crown length and height. Each point is a measured stem: squares = dead, triangles = live. All other variables are held at their mean values.

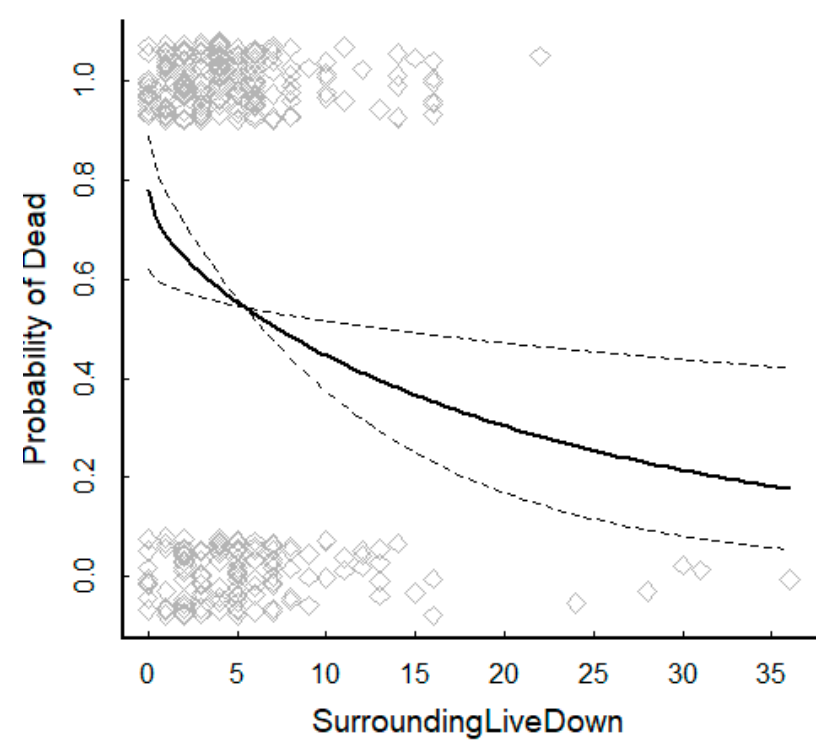

Figure 5. Relationship between probability of mortality of a tree and the number of surrounding live or downed trees. Points are individual trees that either died (top of axis) or remained alive (bottom of axis). Dashed lines are $90 \%$ confidence intervals on the relationship. All other variables are held at their mean values.

The number of cankers and the presence of rodent wounds affected tree survivorship (Table 4). Interestingly, there were opposite effects depending on the lesion type. As the number of cankers increased, the probability of post-harvest survivorship decreased. Although rodent wounds were not tallied, any rodent damage indicated higher survivorship. The canker association was included in the best model for windthrown trees but not when snags were included. The average pre-harvest canker-free tree would have a 50-60\% chance of survival (Figure 6). With one or more cankers, there would be less than a $50 \%$ chance of survival. 


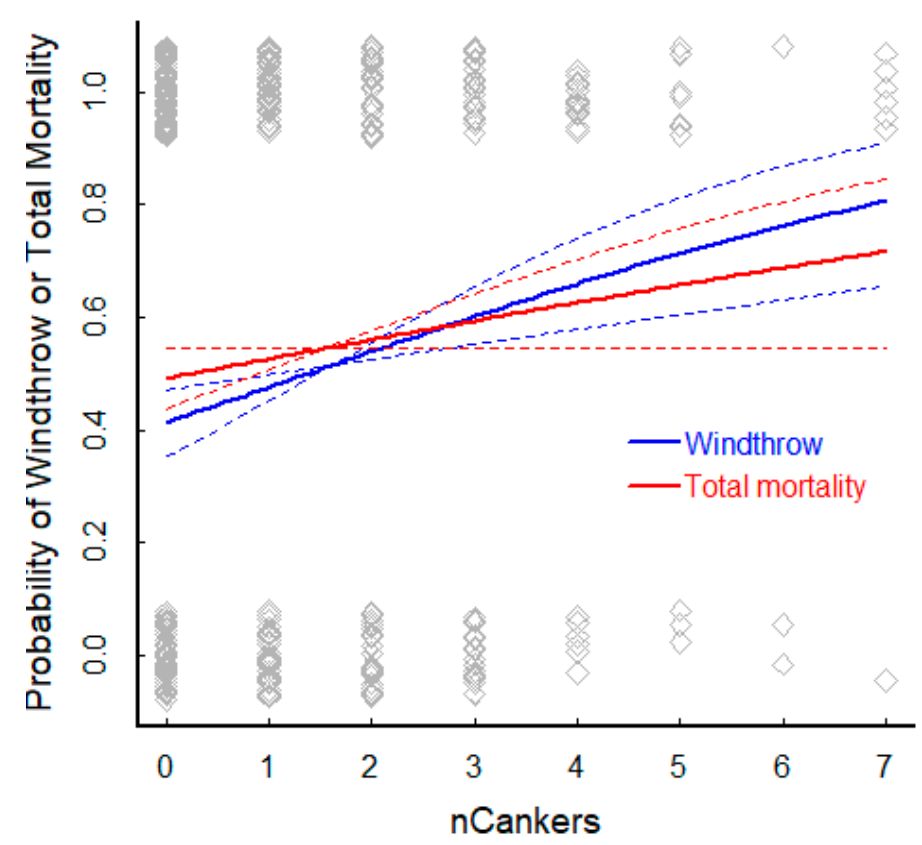

Figure 6. Relationship between the combined probability of windthrow and standing death of a tree and the number of cankers. All other variables are held at their mean values. Points are individual trees that either died (top of axis) or remained alive (bottom of axis). Dashed lines are $90 \%$ confidence intervals on the relationship.

\section{Discussion}

\subsection{Attrition Rates and Wind}

For all harvest sites in this study, elevated mortality rates occurred during the initial post-harvest period. The majority of survivorship chronologies in North America are generated from the boreal region of Canada, where similar trends have been described. For forests dominated by white spruce and quaking aspen (Populus tremuloides Michx.), initial annual mortality rates of retained trees can range from $4 \%$ to $6 \%$ during the first five years post-harvest $[18,33,34]$. Whitebark pine at our sites ranged from $3 \%$ to $16 \%$ of annual mortality rates during the first five years. Mortalities are at least a partial reflection of "harvest shock", where the removal of surrounding trees exposes the retained tree to a dramatically heavier wind load. Retained trees can respond through acclimative growth. This is an adaptive process, altering morphology and strengthening roots, stems and branches [35]. Due to a paucity of research, it is unclear how whitebark pine compares with the capabilities of other tree species. Alternate species were not retained in our study sites, except at Lavington with very low numbers. Although stronger stem reaction wood is a response observed across many species [36], this biomechanical improvement may require a longer time period for high-elevation trees due to their slower radial growth rates [20].

The overall rates of attrition between sites varied noticeably. Although we have identified important biophysical variables associated with tree survivorship (Table 4), additional site-level influences may be important. Identifying significant site variables requires a much greater number of sites to be analyzed-greater than the number of whitebark pine harvest sites currently available in southern British Columbia.

The results suggest that most trees fell during windy conditions. Storm systems that track eastward from the Pacific towards the southern interior of British Columbia are commonly associated with strong winds from the southwest or west. These storms are classified as mid-latitude cyclones and can be consistent generators of strong southwesterly or westerly winds in the winter, especially when they tap into a feed of subtropical moisture commonly referred to as an "atmospheric river". During summer, strong wind events are also common, and are typically associated with downdrafts from passing convective cells or thunderstorms. Winds during these storms can be multi-directional, as downbursts 
exiting the bottom of a storm generally spread in an outward direction from the base of the convective feature.

The predominant directions of downed stems were between $0^{\circ}-90^{\circ}(74 \%$ of windthrown trees). Although slope and aspect likely played a small role in direction of falls (Table 4), only $29 \%$ of downed stems were rooted on aspects of $0^{\circ}-90^{\circ}$ (Figure 3 ). We suggest that winter storms and approaching fronts of coastal low-pressure systems are the most significant drivers of blowdown for whitebark pine stands in the southern interior region. For at least one harvest site, a majority of trees were blown over while alive (Figure 2). As harvest operations were being completed at Lavington (LV), a strong coastal low-pressure system arrived. Gale-force gusts $(61 \mathrm{~km} / \mathrm{h})$ were 18 weather station, indicating the secondhighest recorded windspeed between 1992 and 2019. Our findings are consistent with other observations in the interior, where windthrow direction was predominantly affected by southwesterly winds [17,37]. Lanquaye-Opoku and Mitchell [38] described how interior British Columbia windthrow patterns tend to reflect large-scale synoptic events more than any smoothing effect of local topography.

\subsection{Number of Disease Cankers}

The likelihood of post-harvest mortality is positively associated with the number of blister rust cankers. The relationship is weaker when snags are combined with windthrow (Table 4, Figure 6). Because snags tended to suffer greater surface weathering than windthrown trees, it is possible that some evidence of cankers had deteriorated. Branches and tops were sometimes absent, further reducing the potential evidence of cankers.

Fungal hyphae associated with cankers are known to spread through vascular tissue, extracting nutrients from host cells and decreasing tree fitness [39]. Physically disruptive cankers erupting through bark further hinder nutrient flow, while exposing the cambium to desiccation and colonisation by other pathogens and insects [40]. Although cankered mature trees can survive for decades, if Cronartium ribicola remains in the host, chronic stress may interfere with physiological mechanisms that contribute to windfirmness. Cronartium ribicola is not known to infect root systems; however, the investigation of potential links between above-ground infection and root dynamics may prove relevant.

\subsection{Rodent Damage}

We expected both rodent damage, primarily red squirrel (Tamiasciurus hudsonicus Erxleben) wounding, and cankers to exhibit similar positive associations with mortality. Contrary to expectations, we found higher survival in trees damaged by rodents (Table 4). Wounding was characterized by small patches of missing bark and underlying cambial removal on stems and branches. For live trees, we found that unless rodent wounds encircled branches or stems, there was little if any dieback in tree structure. The majority of rodent damage was in crowns where the risk of decay is much lower than in lower stem wounds [41]. Cambium-feeding mammals in western North America select the fastest growing trees within younger stands [42,43]. Interestingly, following damage on lower boles, trees survived and displayed accelerated radial growth [42]. Rodent damage may therefore indicate healthier trees that can adapt more quickly to post-harvest exposure.

\subsection{Tree Heights and Crown Lengths}

The probability of survival was lower for trees with shorter crown lengths and greater heights (Figure 4). As trees gain height, they are more prone to the lateral force of winds. Stathers and others [20] estimated that a 30-m-tall tree experiences as much as three times the wind torque of a $10-\mathrm{m}$-tall tree. Although retained trees in our study were not this tall, we estimate that a $25-\mathrm{m}$-tall whitebark pine is eight times more likely to die than a 10 -m-tall tree. Trees over $17.5 \mathrm{~m}$ had less than a 50\% chance of surviving. Shorter crown lengths were also associated with lowered survivorship probability. Our findings may seem inconsistent with the perception that lesser crown area would reduce area exposed to wind, thus promoting resiliency. Reduced crown size may indicate root disease; however, 
no signs of disease were found in our field inspections of upturned roots. Trees with narrower crowns have been shown to have less extensive root systems, thus increasing risk to wind [44], and we suspect that the same is happening with shorter crowns. Trees that grew in denser stands with resultingly shorter crowns may be less adapted to resisting windthrow when they are exposed at harvest.

Stem measurements of diameter and the height-to-diameter ratio were not found to be as useful predictors of survival as height and crown length. Although findings from boreal species indicate that diameter and height-to-diameter are often important $[18,45,46]$, Huggard and others [17] found only height-to-diameter to be a significant factor.

\subsection{Surrounding Trees}

Based on the relationship between survivorship and the number of surrounding trees (Figure 5), harvest prescriptions that retain a minimum of eight neighbor trees can expect a better than $50 \%$ chance of survival (for a tree representing the average measurements in our study). Our results are consistent with the vast majority of retention studies, indicating that higher retention levels favor positive survivorship rates (e.g., [33,47-49]). Hallinger and others [19] found an exception with Norway spruce (Picea abies L.), in which dense retention may have created intense competition and mortality; however, Scots pine (Pinus sylvestris L.) survivorship was significantly higher. Increased retention benefits trees that are more prone to windthrow, such as tall trees with short crowns. Our survivorship findings are limited to the post-harvest time intervals that our data represent (17 years maximum). However, the cessation of mortality at 8-9 years post-harvest indicates that this curve remains essentially unchanged.

\subsection{Other Potential Factors}

In our study, pre-harvest stand canopy height and high stem density likely affected survivorship. Prior to harvest, all our study sites were closed canopy stands supporting whitebark pine at above-average heights for the species in the region. Trees with shorter crowns contributed to a top-heavy morphology, and were thus susceptible to wind toppling [20]. The soil structure differed between sites, based on pre-harvest planning surveys. In general, poor soil drainage and lower depth increase the likelihood of blowdown [35]. Perhaps incongruently with our expectations based on soil drainage, we found the highest probability of death at Lavington and lowest probability at Findlay West. However, soil rooting depth at Lavington averaged $42 \mathrm{~cm}$, which is somewhat shallow, therefore contributing to windthrow potential. Additional factors determining tree survivorship that we did not assess include rooting structure, soil depth and moisture.

\section{Conclusions}

Harvest planners should carefully consider the potential outcomes associated with retention harvesting in whitebark pine forests. Practitioners can expect an initial period of high mortality for the first five years post-harvest, followed by lower mortality rates after 8-9 years. Based on our findings, we recommend putting an emphasis on the retention of mature trees with longer crown lengths and lower frequencies of disease cankers. Less retention effort needs to be directed towards trees above average height, as these have a substantially greater probability of windthrow. Retaining a minimum of eight neighboring whitebark pine trees (within the target tree's height radius) will increase the probability of survivorship. Beyond our findings, we acknowledge that retaining cone-producing whitebark pine trees will benefit wildlife and ensure bird-dispersal of seeds, which is the primary vehicle for regeneration.

Because our spatial windfall patterns, as determined by wind direction, are consistent with the established literature from the interior, published recommendations should be considered for whitebark pine. The British Columbia Interior exhibits recurrent storm patterns that tend to topple trees on the southwestern edges of forest patches $[37,38]$. Accounting 
for the predominant direction of windfall in our study, it is recommended that harvest planners lay out ovate patches of retention oriented on a southwest-to-northeast azimuth.

Carefully executed operations may improve conditions for whitebark pine trees. As a poor competitor with late-seral species, most commonly Engelmann spruce and subalpine fir, the removal of competing neighbors will likely benefit whitebark pines in closed-canopy stands. We found increased radial growth rates beginning 1-3 years after harvest, reflecting the findings of other studies [50,51]. Furthermore, harvesting of lodgepole pine may reduce mountain pine beetle attacks [52].

Our findings revealed a substantial variation between sites and should be considered as preliminary results. With any continuance of high-elevation harvesting, the examination of additional harvest locations will improve our understanding of both site and finer-scale biophysical factors. Findings from this study-in concert with empirical experience gained by local harvest practitioners-can improve the likelihood of greater conservation of this important species.

Supplementary Materials: The following is available online: https://www.mdpi.com/article/10.3 390/f12060654/s1.

Author Contributions: Conceptualisation, acquisition of funding, study site selection, field training, original draft preparation by M.P.M.; field sampling performed by J.B. and M.P.M.; methodology by M.P.M., J.B. and D.J.H.; dendrochronology performed by J.B.; regression analysis programmed by D.J.H. All authors have read and agreed to the published version of the manuscript.

Funding: This research was supported by the British Columbia Ministry of Lands and Natural Resource Operations and the Genetics Conservation Technical Advisory Committee of the Forest Genetics Council of BC.

Acknowledgments: We extend our appreciation to staff within our Ministry: Katy Fraser, Marnie Duthie-Holt, Jesse Ellis, Roger Powell, Peter Vandenbergh, Jodi Axelson and Tara DeCourcy. Thanks also to Jamie Hibberson and David Karassowitsch (InterFor), Stephanie Keightley (CanFor), Randy Moody, Paul Mozin and Stephen Mitchell.

Conflicts of Interest: The authors declare no conflict of interest.

\section{References}

1. Cross, P. The Slyest Seed Predator: Interactions between Red Fox and Whitebark Pine in the Greater Yellowstone Ecosystems. Nutcracker Notes 2015, 28, 10-12.

2. Hamer, D.; Pengelly, I. Whitebark Pine (Pinus albicaulis) Seeds as Food for Bears (Ursus spp.) in Banff National Park, Alberta. Can. Field-Nat. 2015, 129, 8-14. [CrossRef]

3. Tomback, D.F. Foraging Strategies of Clark's Nutcracker. Living Bird 1978, 16, 123-161.

4. Morgan, C.; Losey, A.; Adams, R. High-Altitude Hunter-Gatherer Residential Occupations in Wyoming's Wind River Range. N. Am. Archaeol. 2012, 33, 35-79. [CrossRef]

5. Canada Order Amending Schedule 1 to the Species at Risk Act (Volume 146, Number 14, 2012)_Public Consultation SearchSpecies at Risk Registry 2012. Available online: https://species-registry.canada.ca/index-en.html\#/consultations/2410 (accessed on 20 May 2021).

6. Mahalovich, M.; Stritch, L. Pinus albicaulis. The IUCN Red List of Threatened Species 2013: e.T39049A2885918. 2013. Available online: https:/ / dx.doi.org/10.2305/IUCN.UK.2013-1.RLTS.T39049A2885918.en (accessed on 20 May 2021).

7. Smith, C.M.; Shepherd, B.; Gillies, C.; Stuart-Smith, J. Changes in Blister Rust Infection and Mortality in Whitebark Pine over Time. Can. J. For. Res. 2013, 43, 90-96. [CrossRef]

8. Goeking, S.A.; Izlar, D.K. Pinus albicaulis Engelm. (Whitebark Pine) in Mixed-Species Stands throughout Its US Range: Broad-Scale Indicators of Extent and Recent Decline. Forests 2018, 9, 131. [CrossRef]

9. Murray, M.P.; Moody, R. Blister Rust Infection Trends and Distribution in Southern British Columbia's Endangered Whitebark Pine. In Proceedings of the IUFRO 2019 Joint Conference: Genetics of Five-Needle Pines \& Rusts of Forest Trees, Invermere, BC, Canada, 22-26 July 2019.

10. Keating, B. Conservation Group Claims B.C. Company Is "Liquidating” Endangered Trees | CBC News. Available online: https://www.cbc.ca/news/canada/british-columbia/whitebark-pine-endangered-1.5218268 (accessed on 24 March 2021).

11. Parfitt, B. Thousands of B.C.'s Endangered Whitebark Pine Logged on Private Land. Available online: https://thenarwhal.ca/ thousands-of-b-c-s-endangered-whitebark-pine-logged-on-private-land/ (accessed on 8 December 2020).

12. Hoff, R.J.; Bingham, R.T.; McDonald, G.I. Relative Blister Rust Resistance of White Pines. Eur. J. For. Pathol. 1980, 10, 307-316. [CrossRef] 
13. Mahalovich, M.F.; Dickerson, G.A. Whitebark Pine Genetic Restoration Program for the Intermountain West (United States). In Proceedings of the RMRS-P-32, Breeding and Genetic Resources of Five-Needle Pines: Growth, Adaptability, and Pest Resistance, Medford, OR, USA, 23-27 July 2001; U.S. Department of Agriculture, Forest Service, Rocky Mountain Research Station: Fort Collins, CO, USA, 2004; pp. 181-187.

14. Schoettle, A.W.; Klutsch, J.G.; Sniezko, R.A. Integrating Regeneration, Genetic Resistance, and Timing of Intervention for the Long-Term Sustainability of Ecosystems Challenged by Non-Native Pests-A Novel Proactive Approach. In Proceedings of the Fourth International Workshop on the Genetics of Host-Parasite Interactions in Forestry: Disease and Insect Resistance in Forest Trees; Sniezko, R.A., Yanchuk, A.D., Kliejunas, J.T., Palmieri, K.M., Alexander, J.M., Frankel, S.J., Eds.; tech. coords; General Technical Report PSW-GTR-240; U.S. Department of Agriculture, Forest Service, Pacific Southwest Research Station: Albany, CA, USA, 2012; Volume 240, pp. 112-123.

15. Thorpe, H.C.; Thomas, S.C. Partial Harvesting in the Canadian Boreal: Success Will Depend on Stand Dynamic Responses. For. Chron. 2007, 83, 319-325. [CrossRef]

16. Bladon, K.D.; Lieffers, V.J.; Silins, U.; Landhäusser, S.M.; Blenis, P.V. Elevated Mortality of Residual Trees Following Structural Retention Harvesting in Boreal Mixedwoods. For. Chron. 2008, 84, 70-75. [CrossRef]

17. Huggard, D.J.; Klenner, W.; Vyse, A. Windthrow Following Four Harvest Treatments in an Engelmann Spruce-Subalpine Fir Forest in Southern Interior British Columbia, Canada. Can. J. For. Res. 1999, 29, 1547-1556. [CrossRef]

18. Xing, D.; Nielsen, S.E.; Macdonald, S.E.; Spence, J.R.; He, F. Survival and Growth of Residual Trees in a Variable Retention Harvest Experiment in a Boreal Mixedwood Forest. For. Ecol. Manag. 2018, 411, 187-194. [CrossRef]

19. Hallinger, M.; Johansson, V.; Schmalholz, M.; Sjöberg, S.; Ranius, T. Factors Driving Tree Mortality in Retained Forest Fragments. For. Ecol. Manag. 2016, 368, 163-172. [CrossRef]

20. Stathers, R.J.; Rollerson, T.P.; Mitchell, S.J. Windthrow Handbood for British Columbia Forests; BC Ministry of Forests: Victoria, BC, Canada, 1994.

21. Meidinger, D.V.; Pojar, J. Ecosystems of British Columbia; Special Report Series; BC Ministry of Forests: Victoria, BC, Canada, 1991; p. 342.

22. MacKillop, D.; Ehman, A.; Ryan, M. A Field Guide to Ecosystem Classification and Identification for Southeast British Columbia: Four Biogeoclimatic Subzones/Variants in the Boundary-Okanagan: Temporary Supplement to Land Management Handbook 70; B.C. Ministry of Forests, Lands and Natural Resource Operations: Victoria, BC, Canada, 2016.

23. MacKillop, D.J.; Ehman, A.J. A Field Guide to Ecosystem Classification and Identification for Southeast British Columbia: The East Kootenay; Land Management Handbook; B.C. Ministry of Forests, Lands and Natural Resource Operations: Victoria, BC, Canada, 2018; p. 501.

24. Klinka, K.; Chen, H.Y.H.; Wang, Q.; Carter, R.E. Height Growth-Elevation Relationships in Subalpine Forests of Interior British Columbia. For. Chron. 1996, 72, 193-198. [CrossRef]

25. Murray, M.P. Annual Observations of Conspicuous Canker Activity on Whitebark Pine (2003 to 2007). In Future of High-Elevation, Five-Needle White Pines in Western North America, Proceedings of the High Five Symposium, Missoula, MT, USA, 28-30 June 2010; Keane, R.E., Tomback, D.F., Murray, M.P., Smith, C.M., Eds.; Proceedings RMRS-P-63; US Department of Agriculture, Forest Service, Rocky Mountain Research Station: Fort Collins, CO, USA, 2011; Volume 63, pp. 235-237.

26. Hoff, R.J. How to Recognize Blister Rust Infection on Whitebark Pine; U.S. Department of Agriculture, Forest Service, Intermountain Research Station: Ogden, UT, USA, 1992; p. INT-RN-406.

27. Stokes, M.A.; Smiley, T.L. An Introduction to Tree-Ring Dating; Stokes, M.A., Smiley, T.L., Eds.; The University of Arizona Press: Tucson, AZ, USA, 1996.

28. Larsson, L. CooRecorder and Cdendro Programs of the CooRecorder. Cdendro Package Version 7. 2014. Available online: http:/ / www.cybis.se/forfun/dendro/ (accessed on 17 May 2021).

29. Holmes, R.L.; Adams, R.K.; Fritts, H.C. Tree-Ring Chronologies of Western North America: California, Eastern Oregon and Northern Great Basin with Procedures Used in the Chronology Development Work Including Users Manuals for Computer Programs COFECHA and ARSTAN; Laboratory of Tree-Ring Research Archives, The University of Arizona: Tucson, AZ, USA, 1986.

30. Burnham, K.P.; Anderson, D.R. Practical Use of the Information-Theoretic Approach. In Model Selection and Inference: A Practical Information-Theoretic Approach; Burnham, K.P., Anderson, D.R., Eds.; Springer: New York, NY, USA, 1998; pp. 75-117. ISBN 978-1-4757-2917-7.

31. Venebles, W.N.; Ripley, B.D. Modern Applied Statistics with S, 4th ed.; Springer: New York, NY, USA, 2002.

32. R Core Team. R: A Language and Environment for Statistical Computing; R Foundation for Statistical Computing: Vienna, Austria, 2021.

33. Montoro Girona, M.; Morin, H.; Lussier, J.-M.; Ruel, J.-C. Post-Cutting Mortality Following Experimental Silvicultural Treatments in Unmanaged Boreal Forest Stands. Front. For. Glob. Chang. 2019, 2. [CrossRef]

34. Solarik, K.A.; Volney, W.J.A.; Lieffers, V.J.; Spence, J.R.; Hamann, A. Factors Affecting White Spruce and Aspen Survival after Partial Harvest. J. Appl. Ecol. 2012, 49, 145-154. [CrossRef]

35. Mitchell, S.J. Wind as a Natural Disturbance Agent in Forests: A Synthesis. For. Int. J. For. Res. 2013, 86, 147-157. [CrossRef]

36. Du, S.; Yamamoto, F. An Overview of the Biology of Reaction Wood Formation. J. Integr. Plant Biol. 2007, 49, 131-143. [CrossRef]

37. Burton, P. Windthrow Patterns on Cutblock Edges and in Retention Patches in the SBSmc. In Proceedings of the Windthrow Researchers Workshop; University of British Columbia: Richmond, BC, Canada, 2001; pp. 19-31. 
38. Lanquaye-Opoku, N.; Mitchell, S.J. Portability of Stand-Level Empirical Windthrow Risk Models. For. Ecol. Manag. 2005, 216, 134-148. [CrossRef]

39. Geils, B.W.; Vogler, D.R. A Natural History of Cronartium Ribicola. In The Future of High-Elevation, Five-Needle White Pines in Western North America, Proceedings of the High Five Symposium, Missoula, MT, USA, 28-30 June 2010; Keane, R.E., Tomback, D.F., Murray, M.P., Smith, C.M., Eds.; Proceedings RMRS-P-63; U.S. Department of Agriculture, Forest Service, Rocky Mountain Research Station: Fort Collins, CO, USA, 2011; Volume 63, pp. 210-217.

40. Geils, B.W.; Hummer, K.E.; Hunt, R.S. White Pines, Ribes, and Blister Rust: A Review and Synthesis. For. Pathol. 2010, 40, 147-185. [CrossRef]

41. Zeglen, S. British Columbia. Ministry of Forests and Lands. In Tree Wounding and Partial-Cut Harvesting: A Literature Review; Vancouver Forest Region: Nanaimo, BC, Canada, 1997; ISBN 978-0-7726-3206-7.

42. Miller, R.E.; Anderson, H.W.; Reukema, D.L.; Max, T.A. Growth of Bear-Damaged Trees in a Mixed Plantation of Douglas-Fir and Red Alder; Res. Pap. PNW-RP-571; U.S. Department of Agriculture, Forest Service, Pacific Northwest Research Station: Portland, OR, USA, 2007; 29p. [CrossRef]

43. Krebs, J. Porcupine Populations and Winter Feeding Damage in Thinned and Unthinned Second-Growth Stands; University of Alberta: Calgary, AB, USA, 1994.

44. Smith, J.H.G. Root Spread Can Be Estimated from Crown Width of Douglas Fir, Lodgepole Pine, and Other British Columbia Tree Species. For. Chron. 1964, 40, 456-473. [CrossRef]

45. Hämäläinen, A.; Hujo, M.; Heikkala, O.; Junninen, K.; Kouki, J. Retention Tree Characteristics Have Major Influence on the Post-Harvest Tree Mortality and Availability of Coarse Woody Debris in Clear-Cut Areas. For. Ecol. Manag. 2016, 369, 66-73. [CrossRef]

46. Lavoie, S.; Ruel, J.-C.; Bergeron, Y.; Harvey, B.D. Windthrow after Group and Dispersed Tree Retention in Eastern Canada. For. Ecol. Manag. 2012, 269, 158-167. [CrossRef]

47. Busby, P.E.; Adler, P.; Warren, T.L.; Swanson, F.J. Fates of Live Trees Retained in Forest Cutting Units, Western Cascade Range, Oregon. Can. J. For. Res. 2011. [CrossRef]

48. Moussaoui, L.; Leduc, A.; Girona, M.M.; Bélisle, A.C.; Lafleur, B.; Fenton, N.J.; Bergeron, Y. Success Factors for Experimental Partial Harvesting in Unmanaged Boreal Forest: 10-Year Stand Yield Results. Forests 2020, 11, 1199. [CrossRef]

49. Rosenvald, R.; Lõhmus, A.; Kiviste, A. Preadaptation and Spatial Effects on Retention-Tree Survival in Cut Areas in Estonia. Can. J. For. Res. 2008, 38, 2616-2625. [CrossRef]

50. Keane, R.E.; Gray, K.L.; Dickinson, L.J. Whitebark Pine Diameter Growth Response to Removal of Competition; Res. Note RMRS-RN-32; U.S. Department of Agriculture, Forest Service, Rocky Mountain Research Station: Fort Collins, CO, USA, 2007; 9p. [CrossRef]

51. Retzlaff, M.L.; Keane, R.E.; Affleck, D.L.; Hood, S.M. Growth Response of Whitebark Pine (Pinus albicaulis Engelm) Regeneration to Thinning and Prescribed Burn Treatments. Forests 2018, 9, 311. [CrossRef]

52. Maher, C.T.; Nelson, C.R.; Larson, A.J.; Sala, A. Ecological Effects and Effectiveness of Silvicultural Restoration Treatments in Whitebark Pine Forests. For. Ecol. Manag. 2018, 429, 534-548. [CrossRef] 